\title{
Self-management: one size does not fit all
}

Jaap Trappenburg, Tiny Jaarsma, Harmieke van Os-Medendorp, Helianthe Kort, Niek de Wit, Arno Hoes and Marieke Schuurmans

\section{Linköping University Post Print}

\section{Tweet}

N.B.: When citing this work, cite the original article.

Original Publication:

Jaap Trappenburg, Tiny Jaarsma, Harmieke van Os-Medendorp, Helianthe Kort, Niek de Wit, Arno Hoes and Marieke Schuurmans, Self-management: one size does not fit all, 2013, Patient Education and Counseling, (92), 1, 134-137.

http://dx.doi.org/10.1016/j.pec.2013.02.009

Copyright: Elsevier

http://www.elsevier.com/

Postprint available at: Linköping University Electronic Press

http://urn.kb.se/resolve?urn=urn:nbn:se:liu:diva-96406 


\section{Self-management: one size does not fit all}

\section{Letter to the editor}

Jaap Trappenburg, PhD, PT

University Medical Center Utrecht

Department of Rehabilitation, Nursing Science \& Sports

Heidelberglaan 100

PO 85500

3508 GA Utrecht

The Netherlands

j.c.a.trappenburg@umcutrecht.nl

\section{Nini Jonkman, MSc}

University Medical Center Utrecht

Department of Rehabilitation, Nursing Science \& Sports

Heidelberglaan 100

PO 85500

3508 GA Utrecht

The Netherlands

N.Jonkman@umcutrecht.nl

Tiny Jaarsma, PhD, MD

University of Linköping

Department of Social and Welfare studies

Division of Health, Activity and Care

58183 LINKÖPING

Sweden

tiny.jaarsma@liu.se

Harmieke van Os-Medendorp, PhD, RN

University Medical Center Utrecht

Department of Dermatology

Heidelberglaan 100

PO 85500

3508 GA Utrecht

The Netherlands

\section{Helianthe Kort, PhD}

Eindhoven University of Technology /

University of Applied Sciences Utrecht

Den Dolech 2

PO 513

$5600 \mathrm{MB}$ Eindhoven

Niek de Wit, PhD, MD

University Medical Center Utrecht

Julius Center for Health Sciences and Primary Care

Heidelberglaan 100

PO 85500 
3508 GA Utrecht

The Netherlands

\section{Arno Hoes PhD, MD}

University Medical Center Utrecht

Julius Center for Health Sciences and Primary Care

Heidelberglaan 100

PO 85500

3508 GA Utrecht

The Netherlands

Marieke Schuurmans, PhD, RN

University Medical Center Utrecht

Department of Rehabilitation, Nursing Science \& Sports

Heidelberglaan 100

PO 85500

3508 GA Utrecht

The Netherlands

M.J.Schuurmans@umcutrecht.nl 


\section{Self-management and the chronic disease epidemic}

Chronic diseases are the leading causes of mortality, accounting for $60 \%$ of all deaths worldwide ${ }^{1}$. Driven by an aging population, demographic trends, future life-style patterns and changes in diagnostics, future projections indicate that the burden of chronic disease will substantially increase over the next decennia ${ }^{2 ; 3}$. The number of patients suffering from multiple chronic conditions will show a proportionally large increase. The burden of meeting the needs of this growing number of people will fall upon already over-stretched health care services that are struggling to cope with the demands of acute care let alone the needs of those with long-term health condition ${ }^{4}$. As a result, there has been a shift away from paternalistic models of health care that sited the patient in the role of passive recipient towards more active involvement of patients in dealing with the day-to-day realities of chronic disease $\mathrm{5}^{5}$. A promising approach to improving outcomes and reducing health care costs associated with chronic conditions is "self-management," whereby individuals, in collaboration with health-care professionals, assume greater responsibility for health care decisions ${ }^{5}$. Selfmanagement is one of the four major components of the Chronic Care Model and involves both the community and the health-care system ${ }^{6}$. It presupposes that when "Informed Activated Clients" interact with a "Prepared, Proactive, Practice Team," the results are improved functional and clinical outcomes ${ }^{4}$.

It is important to understand the difference between self-management support and patient education, given that these terms are often mistakenly used synonymously. The goals of selfmanagement support are different from of patient education. Patient education refers to traditional, largely didactic, instruction provided to patients which focuses mainly on transfer of knowledge. Selfmanagement support is defined as the systematic provision of supportive interventions by health care staff to increase patients' skills and confidence in managing their health problems, including regular assessment of progress and problems, goal setting, and problem-solving support ${ }^{7}$. Although self-management interventions often also contain didactic strategies, the pivotal objective is to change behavior, which is essential to boot a sequence of effects ${ }^{8}$. Improved self-management behavior is expected to lead to better disease control which should, in turn, lead to better patient outcomes, reduced use of health care services and ultimately to reduced costs and increased patient satisfaction. Core self-management behavioral skills are problem solving, decision making, effective resource utilization, forming of a patient/health care provider partnership, and taking action ${ }^{9}$.

\section{Self-management: is it effective?}

Over the past decade self-management programs have been developed with good progress and a gradually increasing body of evidence. Table 1 illustrates the pooled evidence from meta-analyses emerging, which indicates that self-management in patients with, asthma ${ }^{10}$, chronic heart failure ${ }^{11}$, 
COPD $^{12}$, diabetes type-2 $(\mathrm{DM}-\mathrm{II})^{13}$, hypertension ${ }^{14}$, musculoskeletal pain $^{15}$ and patients on oral anticoagulation ${ }^{16}$ improves a variety of outcomes such as improved disease-specific outcomes, quality of life, self-management behavior, and reduced healthcare costs. Given these encouraging results one might conclude that nothing should prevent policy makers and healthcare professionals from robust implementation of self-management in routine care. Although improving patients' selfmanagement skills apparently seems meaningful and harmless, in 2012 alone three large trials reported negative ${ }^{17}$ or even adverse outcomes including unexplained higher mortality rates ${ }^{18 ; 19}$ (one mainly focusing at telemonitoring). This might indicate that self-management interventions are not necessarily harmless. Should this temper our enthusiasm for self-management support? Forest plots in meta-analyses seem to favor self-management, yet it is important to realize that available trials are characterized by large heterogeneity in self-management approaches in terms of mode, dose, intensity, delivery, etc., resulting in large variance in effect sizes. This substantially hampers our understanding of the effectiveness of self-management.

\section{Self-management: what works best?}

Several meta-analysis have attempted to evaluate possible shifts in effect size for different program characteristics but were largely unrevealing ${ }^{11 ; 13 ; 14 ; 20}$. However, in patients with COPD ${ }^{9}$ and asthma ${ }^{11}$ the addition of action plans for self-treatment of exacerbations is associated with a somewhat larger reduction in healthcare utilization. In DM-II, improvements in glycaemic control seem more pronounced when psychosocial behavioral techniques are used ${ }^{20 ; 21}$. The addition of self-adjusted therapy in patients on oral coagulation seems dominant compared to self-monitoring alone in terms of a slightly greater reduction in thromboembolic events and mortality ${ }^{16}$. Generally, it can be concluded that aggregated / subgroup analyses from the literature do not yet sufficiently answer what type of self-management support is most effective. In itself, that is not surprising, since included trials did not only evaluate highly heterogeneous interventions, but also targeted heterogeneous patient populations using varied outcome measures. Presently, evidence is lacking on what is the contribution of each component in explaining variance in effect size. Without this knowledge, compiling an optimal program package in terms of e.g. mode, dose, intensity and delivery is hindered, as are effective implementation strategies.

\section{One size does not fit all: urge for tailored interventions}

A self-management program is not equal to prescribing patients a drug but instead a classic example of a 'complex intervention' - a treatment strategy containing several interacting components and varying dimensions of complexity (i.e. variability in delivery, organizational levels, outcomes, etc. $)^{22}$. When applied to subtly different target populations or healthcare settings these interventions can 
produce substantially variable results. Although we can conclude that self-management is effective in mean group-outcomes, individual trials report that a substantial proportion of patients do not comply or do not respond to these interventions. The large variance in effect size between patients presumes that 'one size does not fit all'. So far, little is known on factors distinguishing compliers and responders from non-compliers and non-responders. It is still unknown whether in this group a subtle change in the components, mode or intensity of a self-management intervention would have been sufficient to optimize outcomes. It is likely that for a selection of patients some selfmanagement assistance is already sufficient in adequately controlling their disease, while other patients only benefit from more intense self-management support, case-management or even passive surveillance (monitoring). Furthermore, it is plausible that a selection of patients particularly benefit from face-to-face contacts, while sophisticated E-health solutions are suitable for other patients. Given the fact that not all patients seem to benefit from current 'one size fits all' interventions, effect size might substantially be increased by tailoring programs to the individual. Increased knowledge on the program- and patient-related facilitators and barriers of success of selfmanagement interventions can facilitate the development of tailored interventions based on individual patient profiles and preferences.

\section{Conclusion and future directions}

Self-management for people with chronic diseases is now widely recognized as an essential part of treatment. Despite the high expectations and the growing body of evidence in terms of effectiveness, a wide application of self-management programs is inhibited due to several challenges. Meta-analytic findings indicate self-management to have added value in only a selection of outcome measures and they report large variance in effect size both between studies and target populations. Worldwide, a variety of complex and multifactorial interventions have been evaluated in very heterogeneous patient populations keeping healthcare professionals guessing on what works best and what works in whom. There is a lack of empirical evidence about the essential features of self-management programs and to what extent and in which direction effect size changes over different target populations. More research is needed to try and establish the optimum design of dynamic selfmanagement programs, whereby content, mode and intensity are tailored based on the particular chronic disease and characteristics of the patient.

In 2011, after receiving a grant from The Netherlands Organization for Health Research and Development (ZonMw) a unique international research collaboration was launched under the acronym TAilored Self-managemenT \& E-health (TASTE). The TASTE research line aims at systematically filling the knowledge gap needed for the development of tailored interventions, including e-health applications, based on individual patient profiles and preferences. More specific 
aims of this research program are to: 1 . further identify (non)compliers and (non)responders, identify determinants of self-management capacity/skills and determinants of change following selfmanagement support, 2. increase the understanding in the dose-response relationship of selfmanagement interventions, 3 . increase the understanding in the essential clinical competences of healthcare providers providing tailored self-management support, 4. develop a generic intervention which allows tailoring mode, dose and content of self-management education, case-management and monitoring according to pre-specified patient profiles and preferences 5. develop diseasespecific modules that can be added to generic self-management interventions, 6. evaluate (costleffectiveness of a generic tailored self-management intervention.

The scientific objectives are carried out in a systematic and carefully phased approach using the model for development of complex interventions ${ }^{22}$. This model serves as a framework to which hierarchical studies of different nature and methodology can be attached. Within TASTE, a lot of attention will be paid to making the most out of what is already known. Innovative techniques such as meta-regression and Individual Patient-Data (IPD) meta-analysis ${ }^{23}$ will be used to systematically unravel success of self-management in terms of patient- and program characteristics.

Consolidation of this research line is strengthened by close collaboration with other universities (both Dutch and abroad), primary care organizations, patient organizations, educational institutes and professional organizations. Involvement of experienced self-management researchers from University Twente (The Netherlands), Leiden University Medical Center (The Netherlands), Linkoping University (Sweden), Stanford University (California, US), McGill University (Canada), Pace University (US), University of Warwick (UK), Taipei University (Taiwan) and University of Leuven (Belgium) substantially contribute to the health behavioral and methodological expertise of the research team. Within this collaboration, TASTE aims at substantially increasing the understanding of the interaction of patient- and program characteristics in defining the success of self-management interventions, which may facilitate the development of future interventions. 
Table 1. Evidence for effectiveness of self-management based on meta-analysis in several chronic conditions.

\begin{tabular}{|c|c|c|c|c|c|c|c|c|c|}
\hline \multirow[t]{3}{*}{ Chronic disease } & \multirow{3}{*}{$\begin{array}{l}\text { Meta- } \\
\text { analysis }\end{array}$} & \multirow[t]{3}{*}{ Comparison } & \multirow{3}{*}{$\begin{array}{l}\text { \# Included } \\
\text { RCT's / } \\
\text { patients }\end{array}$} & \multicolumn{6}{|c|}{ Key significant findings } \\
\hline & & & & \multicolumn{2}{|c|}{ Disease specific outcomes } & \multicolumn{2}{|c|}{ Patient Reported Outcomes } & \multicolumn{2}{|c|}{ Healthcare utilization } \\
\hline & & & & parameter & pooled result & parameter & pooled result & parameter & pooled result \\
\hline $\begin{array}{c}\text { Arthritis / } \\
\text { Chronic } \\
\text { musculo- } \\
\text { skeletal pain } \\
\end{array}$ & $\begin{array}{l}\text { Du et al. } \\
2011\end{array}$ & $\begin{array}{l}\text { Self-management } \\
\text { education vs. usual } \\
\text { care }\end{array}$ & $19 / ?$ & $\begin{array}{l}\text { Arthritis-related pain } \\
4 \text { months } \\
6 \text { months } \\
12 \text { months }\end{array}$ & $\begin{array}{l}\text { SMD: -0.23 [-0.36,-0.10] } \\
\text { SMD: -0.29 [-0.41,-0.17] } \\
\text { SMD: -0.14 [-0.23,-0.04] }\end{array}$ & $\begin{array}{l}\text { Arthritis-related } \\
\text { disability } \\
12 \text { months }\end{array}$ & SMD: -0.17 [-0.27,-0.07] & & \\
\hline Asthma & $\begin{array}{l}\text { Gibson et } \\
\text { al. } \\
2003\end{array}$ & $\begin{array}{l}\text { Self-management } \\
\text { education +/- regular } \\
\text { review vs usual care }\end{array}$ & $36 / 4593$ & $\begin{array}{l}\text { Nocturnal asthma } \\
\text { Peak Flow (I/min) }\end{array}$ & $\begin{array}{l}\text { RR: } 0.67[0.56,0.79] \\
\text { WMD: } 0.18[0.07,0.29]\end{array}$ & $\begin{array}{l}\text { HRQoL } \\
\text { miscellaneous }\end{array}$ & WMD: $0.29[0.11,0.47]$ & $\begin{array}{l}\text { Hospitalization } \\
\text { ER visits } \\
\text { Days off work }\end{array}$ & $\begin{array}{l}\text { RR: } 0.64[0.50-0.82] \\
\text { RR: } 0.82[0.73,0.94] \\
\text { WMD: }-0.18[-0.28,-0.09]\end{array}$ \\
\hline $\mathrm{CHF}$ & \begin{tabular}{|l|} 
Jovicic et al. \\
2006
\end{tabular} & $\begin{array}{l}\text { Self-management } \\
\text { education vs. usual } \\
\text { care }\end{array}$ & $6 / 857$ & & & & & $\begin{array}{l}\text { 1-year readmission } \\
\text { - all cause } \\
\text { - CHF-related }\end{array}$ & $\begin{array}{l}\text { OR: } 0.59[0.44,0.88] \\
\text { OR: } 0.44[0.27,0.71]\end{array}$ \\
\hline COPD & $\begin{array}{l}\text { Effing et al. } \\
2007\end{array}$ & $\begin{array}{l}\text { Self-management } \\
\text { education vs. usual } \\
\text { care }\end{array}$ & $15 / 2239$ & $\begin{array}{l}\text { Dyspnea } \\
\text { Borg scale }\end{array}$ & WMD: -0.53 [-0.96,-0.10] & $\begin{array}{l}\text { HRQoL } \\
\text { SGRQ total }\end{array}$ & SMD: -2.58 [-5.14,-0.02] & $\begin{array}{l}\geq 1 \text { respiratory- } \\
\text { related hospital } \\
\text { admission/year }\end{array}$ & OR: $0.64[0.47,0.89]$ \\
\hline DMII & \begin{tabular}{|l} 
Deakin et \\
al. \\
2009
\end{tabular} & $\begin{array}{l}\text { Group based self- } \\
\text { management vs. usual } \\
\text { care }\end{array}$ & $11 / 1532$ & $\begin{array}{l}\text { HbA1c (\%) } \\
4-6 \text { months } \\
12-14 \text { months } \\
2 \text { years } \\
\text { FB glucose (mmol/L) } \\
12-14 \text { months } \\
\text { Weight }(\mathrm{kg}) \\
12-14 \text { months } \\
\text { SBP (mmHg) } \\
4-6 \text { months }\end{array}$ & $\begin{array}{l}\text { WMD: -1.35 [-1.93,-0.78] } \\
\text { WMD: -0.82 [-0.99,-0.65] } \\
\text { WMD: -0.97 [-1.40,-0.54] } \\
\text { WMD: -1.17 [-1.63,-0.72] } \\
\text { WMD: -1.61 [-2.97,-0.25] } \\
\text { WMD: -5.37 [-9.53,-1.21] }\end{array}$ & \begin{tabular}{|l} 
Diabetes \\
knowledge
\end{tabular} & WMD: $1.0[0.7,1.2]$ & $\begin{array}{l}\text { Diabetes } \\
\text { medication }\end{array}$ & OR: 11.8 [5.2,26.9] \\
\hline $\begin{array}{l}\text { DMII - not using } \\
\text { insuline }\end{array}$ & \begin{tabular}{|l|} 
Malanda et \\
al. \\
2012 \\
\end{tabular} & $\begin{array}{l}\text { Self-monitoring of } \\
\text { blood glucose vs. usual } \\
\text { care }\end{array}$ & $12 / 3259$ & $\begin{array}{l}\text { HbA1c (\%) } \\
6 \text { months }\end{array}$ & WMD: -0.26 [-0.39,-0.13] & & & & \\
\hline Hypertension & $\begin{array}{l}\text { Chodosh et } \\
\text { al } 2005\end{array}$ & $\begin{array}{l}\text { Self-management } \\
\text { education vs usual care }\end{array}$ & $13 / ?$ & $\begin{array}{l}\text { SBP }(\mathrm{mmHg}) \\
\mathrm{DBP}(\mathrm{mmHg})\end{array}$ & $\begin{array}{l}\text { PES: }-0.39[-0.51,-0.28] \\
\text { PES: }-0.51[-0.73,-0.30]\end{array}$ & & & & \\
\hline $\begin{array}{c}\text { Patients on } \\
\text { long-term oral } \\
\text { anticoagulation }\end{array}$ & \begin{tabular}{|l|} 
Garcia- \\
Alamino et \\
al. \\
2012 \\
\end{tabular} & $\begin{array}{l}\text { Self-monitoring }+/- \\
\text { self-management } \\
\text { education vs regular } \\
\text { care }\end{array}$ & $18 / 4723$ & $\begin{array}{l}\text { Thromboembolic } \\
\text { events } \\
\text { All-cause mortality }\end{array}$ & $\begin{array}{l}\text { RR: } 0.50[0.36,0.69] \\
\text { RR: } 0.64[0.46,0.89]\end{array}$ & & & & \\
\hline
\end{tabular}

SMD = Standardized Mean Difference; CHF = Chronic Heart Failure; COPD = Chronic Obstructive Pulmonary Disease; WMD = Weighted Mean Difference; $H R Q o L=$ Health-Related Quality of Life; $S G R Q=S G R Q$ : Saint George Respiratory Disease Questionnaire (lower scores represent better quality of life); DMII = diabetes mellitus type 2; HbA1C = Glycated haemoglobin; FB = Fasting Blood; RR = Risk Ratio; ER = Emergency Room; DBP = Diastolic Blood Pressure; PES = Pooled Effect Size 
(1) Alwan A, World Health Organization. Global status report on noncommunicable diseases 2010. 2011. Geneva, Switzerland, World Health Organization.

Ref Type: Report

(2) Mathers CD, Stevens G, Mascarenhas M. Global health risks: mortality and burden of disease attributable to selected major risks. 2009. Geneva, Switzerland, World Health Organization. Ref Type: Report

(3) Mathers CD, Loncar D. Projections of global mortality and burden of disease from 2002 to 2030. PLoS Med 2006; 3(11):e442.

(4) Wagner EH. Chronic disease management: what will it take to improve care for chronic illness? Eff Clin Pract 1998; 1(1):2-4.

(5) Barlow J, Wright C, Sheasby J, Turner A, Hainsworth J. Self-management approaches for people with chronic conditions: a review. Patient Educ Couns 2002; 48(2):177-187.

(6) Wagner EH, Austin BT, Korff von M. Organizing Care for Patients with Chronic Illness. Milbank Quarterly 1996; 4:511-544.

(7) Adams K, Greiner AC, Corrigan JM. The 1st annual crossing the quality chasm summit: A focus on communities. Washington, DC: National Academies Press; 2004.

(8) Bourbeau J, Nault D, Dang-Tan T. Self-management and behaviour modification in COPD. Patient Educ Couns 2004; 52(3):271-277.

(9) Lorig KR, Holman H. Self-management education: history, definition, outcomes, and mechanisms. Ann Behav Med 2003; 26(1):1-7.

(10) Gibson PG, Powell H, Coughlan J, Wilson AJ, Abramson M, Haywood P et al. Self-management education and regular practitioner review for adults with asthma. Cochrane Database Syst Rev 2003;(1):CD001117.

(11) Jovicic A, Holroyd-Leduc JM, Straus SE. Effects of self-management intervention on health outcomes of patients with heart failure: a systematic review of randomized controlled trials. BMC CardiovasC Disord 2006; 6:43.

(12) Effing T, Monninkhof EM, van der Valk PDLPM, van der Palen J., van Herwaarden CL, Partidge MR et al. Self-management education for patients with chronic obstructive pulmonary disease. Cochrane Database Syst Rev 2007;(4):CD002990.

(13) Deakin T, McShane CE, Cade JE, Williams RD. Group based training for self-management strategies in people with type 2 diabetes mellitus. Cochrane Database Syst Rev 2005;(2):CD003417.

(14) Chodosh J, Morton SC, Mojica W, Maglione M, Suttorp MJ, Hilton L et al. Meta-analysis: chronic disease self-management programs for older adults. Ann Intern Med 2005; 143(6):427-438.

(15) Du S, Yuan C, Xiao X, Chu J, Qiu Y, Qian H. Self-management programs for chronic musculoskeletal pain conditions: a systematic review and meta-analysis. Patient Educ Couns 2011; 85(3):e299-e310. 
(16) Garcia-Alamino JM, Ward AM, onso-Coello P, Perera R, Bankhead C, Fitzmaurice D et al. Selfmonitoring and self-management of oral anticoagulation. Cochrane Database Syst Rev 2010;(4):CD003839.

(17) Bucknall CE, Miller G, Lloyd SM, Cleland J, McCluskey S, Cotton M et al. Glasgow supported selfmanagement trial (GSUST) for patients with moderate to severe COPD: randomised controlled trial. BMJ 2012; 344:e1060.

(18) Takahashi PY, Pecina JL, Upatising B, Chaudhry R, Shah ND, Van HH et al. A Randomized Controlled Trial of Telemonitoring in Older Adults With Multiple Health Issues to Prevent Hospitalizations and Emergency Department Visits. Arch Intern Med 2012.

(19) Fan VS, Gaziano JM, Lew R, Bourbeau J, Adams SG, Leatherman S et al. A comprehensive care management program to prevent chronic obstructive pulmonary disease hospitalizations: a randomized, controlled trial. Ann Intern Med 2012; 156(10):673-683.

(20) Minet L, Moller S, Vach W, Wagner L, Henriksen JE. Mediating the effect of self-care management intervention in type 2 diabetes: a meta-analysis of 47 randomised controlled trials. Patient Educ Couns 2010; 80(1):29-41.

(21) Duke SA, Colagiuri S, Colagiuri R. Individual patient education for people with type 2 diabetes mellitus. Cochrane Database Syst Rev 2009;(1):CD005268.

(22) Craig P, Dieppe P, Macintyre S, Michie S, Nazareth I, Petticrew M. Developing and evaluating complex interventions: the new Medical Research Council guidance. BMJ 2008; 337:a1655.

(23) Stewart LA, Clarke MJ. Practical methodology of meta-analyses (overviews) using updated individual patient data. Cochrane Working Group. Stat Med 1995; 14(19):2057-2079. 